\title{
Callitachykinin I and II, Two Novel Myotropic Peptides Isolated From the Blowfly, Calliphora vomitoria, That Have Resemblances to Tachykinins
}

\author{
C. TOMAS LUNDQUIST, ${ }^{*}$ FRANK L. CLOTTENS,$\dagger$ G. MARK HOLMAN, $\dagger$ RUTHANN NICHOLS, $\ddagger$ \\ RONALD J. NACHMAN† AND DICK R. NÄSSEL*1
}
*Department of Zoology, Stockholm University, S-10691 Stockholm, Sweden, †Food Animal Protection Research Laboratory, United States Department of Agriculture, College Station, TX 77845, †Departments of Biological Chemistry and Biology, University of Michigan, Ann Arbor, MI 48109-1048

\author{
Received 6 December 1993
}

\begin{abstract}
LUNDQUIST, C. T., F. L. CLOTTENS, G. M. HOLMAN, R. NICHOLS, R. J. NACHMAN AND D. R. NÄSSEL. Callitachykinin $I$ and II, two novel myotropic peptides isolated from the blowfly, Calliphora vomitoria, that have resemblances to tachykinins. PEPTIDES 15(5) 761-768, 1994.-Two peptides, related to the locust myotropic peptides locustatachykinin I-IV, were isolated from the blowfly Calliphora vomitoria. Whole, frozen flies were used for extraction with acidified methanol. A cockroach hindgut muscle contraction bioassay was used for monitoring fractions during subsequent purification steps. A series of eight different high performance liquid chromatography column systems was required to obtain optically pure peptides. Two peptides were isolated and their sequences determined by Edman degradation and confirmed by mass spectrometry and chemical synthesis as APTAFYGVR-NH ${ }_{2}$ and GLGNNAFVGVR-NH $\mathrm{N}_{2}$. They were named callitachykinin I and II. The peptides have sequence similarities to the locustatachykinins and vertebrate tachykinins. Both callitachykinins were recognized by an antiserum to locustatachykinin I in enzyme-linked immunosorbent assay (ELISA) tests and callitachykinin II was additionally recognized by an antiserum to the vertebrate tachykinin kassinin, suggesting that immunolabeling of blowfly neurons with these antisera is due to neuronal callitachykinins.
\end{abstract}

Tachykinins Calliphora vomitoria Insect neuropeptide Insect nervous system Locustatachykinin

RECENTLY four myotropic neuropeptides with some sequence homology to vertebrate tachykinins were isolated from extracts of the brain and the corpora cardiaca-corpora allata complex of the locust Locusta migratoria. These peptides were named locustatachykinins I-IV [LomTK I-IV; $(6,33,34)]$. Together with eledoisin, a tachykinin isolated from the salivary glands of the cephalopod Eledone (11), urechistachykinin I and II; isolated from the echiuroid worm, Urechis unicinctus (19) and sialokinin I and II, isolated from the salivary glands of the mosquito Aedes aegypti (2), the LomTKs were to date the only identified invertebrate representatives of this large peptide family. In the locust, Locusta migratoria, these peptides stimulate the contraction of the oviduct and foregut $(33,34)$. Additionally, locustatachykinins stimulate pheromonotropic activity in the pheromone glands of the moth Bombyx mori (13). In the blowfly several, clearly dif- ferent, neuron populations contain material reacting with antisera raised against different tachykinins, including LomTK I $(24,25,31,32)$. The distribution of the immunoreactive material indicates that native tachykinin-related neuropeptides may act as neurotransmitters or neuromodulators in interneuronal circuits in the blowfly central nervous system. LomTK-like immunoreactivity was, in addition, found in intrinsic endocrine cells of the blowfly midgut (25).

To establish some of the functional roles of the tachykininrelated peptides in the blowfly, it is necessary to determine the primary structures of the native neuropeptides. Here we describe the purification and isolation of two novel myotropic, tachykininrelated peptides from blowfly tissue extract. We employed the cockroach hindgut contraction bioassay, earlier used during the isolation of cockroach, locust, and cricket myotropic peptides (18),

\footnotetext{
${ }^{1}$ Requests for reprints should be addressed to Dick R. Nässel.
} 
to monitor the blowfly peptides during purification. The two myotropic peptides isolated and characterized from Calliphora vomitoria extracts are also recognized in a LomTK ELISA. The novel peptides were named callitachykinin I and II.

\section{METHOD}

\section{Animals and Tissue Extraction}

Pupae of the blowfly Calliphora vomitoria were purchased from EKOL AB (Linköping, Sweden). After hatching the flies were collected, frozen, and stored at $-80^{\circ} \mathrm{C}$ until further processing. The rearing of the cockroach Leucophaea maderae, the hindgut preparation, and bioassay are described in detail elsewhere $(5,15,18)$. A total of $3.6 \mathrm{~kg}$ blowflies (about 90,000 whole specimens) was used for extraction. Batches of $120 \mathrm{~g}$ frozen flies were extracted in $1200 \mathrm{ml}$ methanol:water:acetic acid (90:9:1). The flies were homogenized in cold extraction solvent with a Polytron ${ }^{\circledR}$ homogenizer. The homogenate was centrifuged at $8000 \times g$ for $30 \mathrm{~min}$ at $4^{\circ} \mathrm{C}$. The supernatant was filtered through two nylon filter membranes ( $5 \mu \mathrm{m}$ and $1.2 \mu \mathrm{m}$; Poretics Inc., Livermore, CA) placed on top of each other. The filtrate was saved. The pellet was resuspended in $1200 \mathrm{ml}$ fresh extraction solvent, and centrifuged and filtered as above. The filtrates were mixed and diluted in $1 \%$ trifluoroacetic acid (TFA; Sigma, St. Louis, $\mathrm{MO}$ ) in water to a final concentration of $4: 1$ of filtrate and $1 \%$ aqueous TFA and centrifuged $(5500 \times g$ for $30 \mathrm{~min}$ at $4^{\circ} \mathrm{C}$ ). After centrifugation, the supernatant was filtered through an activated and equilibrated Mega Bond Elut ${ }^{\top N} \mathrm{Cl} 8$ cartridge $(60 \mathrm{ml}, 10 \mathrm{~g}$; Varian, Harbour City, CA). After an initial wash with $50 \mathrm{ml}$ of a $4: 1$ mixture of extraction solvent and $1 \%$ aqueous TFA, the filtrate was passed through the column. The eluate was concentrated by rotary evaporation (removal of methanol) and the remainder was applied to an activated and equilibrated C18 Sep-Pak-Vac®) cartridge $(35 \mathrm{ml}, 10 \mathrm{~g}$; Waters/Millipore, Milford, MA). After the extract was bound to the cartridge it was washed with $100 \mathrm{ml} 0.1 \%$ aqueous TFA in water. Subsequently, the extract was eluted with $50 \mathrm{ml}$ each of $10 \%, 30 \%$, $50 \%$, and $80 \%$ acetonitrile (Merck, Darmstadt, Germany) containing $0.1 \%$ aqueous TFA. Tissue ( $60 \mathrm{~g}$ equivalents) was loaded onto the cartridge for each run for a total of 60 runs. Aliquots of the different eluates (representing $1 \mathrm{~g}$ of blowfly tissue) were tested for bioactivity in the Leucophaea hindgut contraction bioassay. The acetonitrile of the different fractions was removed by rotary evaporation and the remainder was freeze-dried until further use.

\section{Purification and Isolation Procedures}

Isolation was performed on a Waters ALC 100 high performance liquid chromatograph equipped with two pumps, a solvent programmer, a Rheodyne septumless injector, and a variable wavelength detector. The peptide material was sequentially eluted through eight different column systems. Aliquots, representing $1-5 \%$ of each fraction, were tested on the hindgut contraction bioassay and the fractions containing myotropic activity were further processed through the next column. The columns and the operating conditions were:

(a) Waters Delta Pak C18, $300 \AA, 15 \mu \mathrm{m}, 25 \times 100 \mathrm{~mm}$ (Waters Assoc., Milford, MA). Solvent A: 0.1\% TFA in water; solvent B: $50 \%$ acetonitrile in $0.1 \%$ aqueous TFA. Conditions: a linear gradient from $0-100 \%$ B over $150 \mathrm{~min}$; flow rate 7.5 $\mathrm{ml} / \mathrm{min}$; $15-\mathrm{ml}$ fractions were collected every $2 \mathrm{~min}$; detector set at 2.0 absorption units full scale (AUFS) at $214 \mathrm{~nm}$. (b) Waters Delta Pak C4, $300 \AA ̊, 15 \mu \mathrm{m}, 25 \times 100 \mathrm{~mm}$ (Waters). Conditions as for (a).

(c) Vydac Phenyl, $300 \AA, 5 \mu \mathrm{m}, 10 \times 250 \mathrm{~mm}$ (Phenomenex, Torrance, CA). Solvents and gradient as for (a); flow rate 2 $\mathrm{ml} / \mathrm{min}$; 4-ml fractions were collected every $2 \mathrm{~min}$; detector set at 4.0 AUFS at $214 \mathrm{~nm}$.

(d) Waters Nova Pak C8, $100 \AA$ A, $4 \mu \mathrm{m}, 8 \times 100 \mathrm{~mm}$ (Waters). Solvents and gradient as for (a); flow rate $1.5 \mathrm{ml} / \mathrm{min} ; 3-\mathrm{ml}$ fractions were collected every $2 \mathrm{~min}$; detector set at 2.0 AUFS at $214 \mathrm{~nm}$.

(e) Vydac Diphenyl, $100 \AA$, $4.6 \times 250 \mathrm{~mm}$ (Phenomenex). Conditions as for (a).

(f) Spherex C18 3-ODS, $4.6 \times 150 \mathrm{~mm}$ (Phenomenex). Solvents as in (a); flow rate $1.0 \mathrm{ml} / \mathrm{min}$; peaks collected manually; detector set at 0.5 AUFS at $214 \mathrm{~nm}$.

(g) I- 125 Waters Protein Pak, $7.8 \times 300 \mathrm{~mm}$ (Waters). Solvent A: $95 \%$ acetonitrile in $0.01 \%$ aqueous TFA; solvent B: $50 \%$ acetonitrile in $0.01 \%$ aqueous TFA. Conditions: $100 \% \mathrm{~A}$ for $8 \mathrm{~min}$, then a linear gradient of $0-100 \%$ B over $80 \mathrm{~min}$; flow rate $1.5 \mathrm{ml} / \mathrm{min}$; peaks collected manually; detector set at 0.2 AUFS at $214 \mathrm{~nm}$.

(h) The last purification step was performed on an Applied Biosystems Microbore HPLC, consisting of a $140 \mathrm{~B}$ solvent delivery system and a 785A programmable absorbance detector. It was equipped with a Progel ${ }^{(\top \mathrm{N})}$-TSK C18 NPR column, $4.6 \times 35 \mathrm{~mm}$ (Supelco, Bellefonte, PA). Solvents: same as for (a). Conditions: $100 \% \mathrm{~A}$ for $3 \mathrm{~min}$, then a linear gradient of $0-100 \%$ B over $50 \mathrm{~min}$; flow rate $100 \mu \mathrm{l} / \mathrm{min}$; peaks were collected manually; detector set at 0.1 AUFS at $214 \mathrm{~nm}$.

\section{Enzymatic Degradation}

Dried aliquots of $1-3 \%$ of each isolated peptide were taken up in $200 \mu \mathrm{l}$ cockroach saline and incubated with one unit of immobilized aminopeptidase $M$ gel suspension (Pierce, Rockford, IL). As a control, an identical set of peptides was taken up in saline only. The mixtures were shaken in a $37^{\circ} \mathrm{C}$ water bath for $2 \mathrm{~h}$. The gel was removed from the suspension by centrifugation and the supernatant was transferred directly to the hindgut bioassay chamber.

\section{Amino Acid Sequence Analysis, Peptide Synthesis, and Mass Spectrometry}

The amino acid sequence of the two isolated peptides was determined with an Applied Biosystems model 473A automated protein sequencer with on-line detection of PTH-amino acids using standard operating conditions. Approximately $100 \mathrm{pmol}$ of each peptide was used for the analysis. The masses of the natural peptides were determined using laser desorption mass spectrometry on a Vestec model 2000 laser desorption time-offlight mass spectrometer. Samples were run in a positive mode using $\alpha$-cyano-4-hydroxycinnamic acid as the matrix. Mass accuracy is generally $0.05 \%$ or better. Calculated average masses were determined using the computer program PROCOMP version 1.2. This program was developed by P. C. Andrews, $\mathrm{PhD}$, University of Michigan, for peptide data manipulations on IBMcompatible computers.

Based on the structural information obtained from the sequence analysis, the two peptides were synthesized by the solidphase peptide synthesis on a Vega coupler 250 automated peptide synthesizer using Fmoc chemistry with diisopropylcarbodiimide as the coupling reagent and dimethylformamide as solvent. The structural identity of the synthetic peptides was confirmed by the presence of the molecular ions $\left(\mathrm{MH}^{+}\right)$in the mass spectra 
taken on a VG-70-250 EHF spectrometer (VG Analytical, Manchester, UK) according to previously described procedures (28). The synthetic peptides were also analyzed by amino acid composition (Table 4) as described earlier (27).

To compare the retention times of the synthetic peptides with the respective natural peptides, a mixture of an equal amount of both synthetic and natural peptides were co-chromatographed on the following analytical HPLC columns:

(a) BioSep Sec-S2000, $7.8 \times 300 \mathrm{~mm}$ (Phenomenex). Solvent A: $95 \%$ acetonitrile in $0.01 \%$ aqueous TFA; solvent B: $50 \%$ acetonitrile in $0.01 \%$ aqueous TFA. Conditions: $100 \%$ A for $8 \mathrm{~min}$, then a linear gradient $0-100 \%$ B over $80 \mathrm{~min}$; flow rate $1.5 \mathrm{ml} / \mathrm{min}$; detector set at 0.1 AUFS at $220 \mathrm{~nm}$.

(b) Vydac Diphenyl, $100 \AA, 4.6 \times 250 \mathrm{~mm}$ (Phenomenex). Solvent $A$ : $0.1 \%$ aqueous TFA; solvent B: $60 \%$ acetonitrile in $0.1 \%$ aqueous TFA. Conditions: a linear gradient from 0 $100 \% \mathrm{~B}$ over $120 \mathrm{~min}$; flow rate $1.5 \mathrm{ml} / \mathrm{min}$; detector set at 0.1 AUFS at $220 \mathrm{~nm}$.

(c) Spherex C18 3-ODS, $4.6 \times 150 \mathrm{~mm}$ (Phenomenex). Same solvents and conditions as (b); flow rate $1.0 \mathrm{ml} / \mathrm{min}$.

(d) Deltabond C8, $5 \mu \mathrm{m}, 4.6 \times 250 \mathrm{~mm}$ (Keystone, Bellefonte, PA). Same solvents and conditions as (b).

(e) Progel ${ }^{\top m}$-TSK C18 NPR, $4.6 \times 35 \mathrm{~mm}$ (Supelco). Same solvents and conditions as described above.

\section{Threshold Concentrations}

The quantity of synthetic peptide was calculated from the value obtained for the phenylalanine in the amino acid analysis. The quantity of natural peptide was calculated from a standard series of known quantities of synthetic peptide on a Vydac Diphenyl column with conditions described for the control of the synthetic peptides. Threshold concentrations were determined by adding known quantities of synthetic and natural peptide to the bioassay chamber containing the Leucophaea hindgut. The threshold concentration is defined as that concentration of peptide that is required to evoke an observable change in frequency, amplitude, or tonus of the spontaneous contractions within 1 min. For each peptide the respectively natural and synthetic peptides were tested on the same hindgut preparation. The threshold was determined from five different hindgut preparations.

\section{Enzyme-Linked Immunosorbent Assay}

Enzyme-linked immunosorbent assay (ELISA) was used qualitatively to test whether the isolated peptides reacted with either of two different tachykinin antisera: one to the frog tachykinin kassinin (36) and one to locustatachykinin I [Lom TK I; $(25,29)]$. The ELISA procedure, using these antisera, is described elsewhere (25). Briefly, the tests were performed as noncompetitive ELISAs with the LomTK I antiserum diluted 1: 2000 and the kassinin antiserum diluted 1:500. One percent aliquots of the purified peptides were coated to the plate (polystyrene MaxiSorp microtiter plates; Nunc, Denmark) and assayed using both antisera. Furthermore, 5\% aliquots of all remaining fractions from the first HPLC column (Delta Pak C18) were also checked in the ELISAs for immunoreactivity.

Finally, an ELISA with a dilution series of the antiserum was run on the synthetic peptides. In this case, the LomTK I antiserum was diluted from $1: 1000$ up to $1 ; 100,000$ with $10 \mathrm{pmol}$ of the peptide coated to the plate. The kassinin antiserum was diluted from 1:500 up to $1: 50,000$ with 100 pmol peptide coated. Each test was performed in duplicate.

\section{RESULTS}

The different acetonitrile fractions that eluted from the SepPak cartridges during the initial extraction were tested for myotropic bioactivity on the cockroach hindgut. Stimulatory effect was detected exclusively in the $30 \%$ acetonitrile fraction. The spontaneous activity was reestablished after rinsing the incubation chamber. The $10 \%$ and $50 \%$ fractions showed inhibitory effects on the spontaneous activity of the hindgut. The $30 \%$ fraction was taken for further purification. The subsequent separation and purification required eight different HPLC column systems. For each system, aliquots of $1-5 \%$ of the collected fractions were screened for myotropic activity on the cockroach hindgut. The $30 \%$ acetonitrile fraction, representing a total of $3.6 \mathrm{~kg}$ blowfly extract, was divided into eight sets and run separately on the first column. Myotropic bioactivity was detected in two regions with retention times of 58-61 and 62-65 min, respectively. The material eluting in these time ranges was further processed separately through all the other columns. The chromatograms of the first five preparative column systems yielded a multitude of UV absorbing peaks (data not shown). The elution times for the myotropic material in each column system are given in Table 1. The chromatograms of the last three column systems are shown in Fig. 1.

On the final column (Progel TSK C18), two pure peptides eluted at 13.5 and $15.0 \mathrm{~min}$, respectively. To determine whether these peptides were $N$-terminally blocked or not, aliquots were treated with the peptide degradation enzyme aminopeptidase $\mathrm{M}$ for $2 \mathrm{~h}$ at $37^{\circ} \mathrm{C}$. The bioactivity was measured in the hindgut bioassay. No activity could be found for either of the two peptides incubated with the enzyme. As a control, aliquots of the peptides were incubated in saline for $2 \mathrm{~h}$ at $37^{\circ} \mathrm{C}$. No loss of the myotropic bioactivity was found in the control conditions.

Aliquots of both peptides, representing approximately 100 pmol, were sequentially degraded with the gas-phase sequencer. The estimation of the aliquots of both peptides was based on the absorption characteristics of 100 pmol of a presumed similar synthetic peptide (LomTK I) applied on the final column (Progel TSK C18), used for the purification of the callitachykinins.

TABLE 1

ELUTION TIMES OF MYOTROPIC MATERIAL DURING PURIFICATION

\begin{tabular}{|c|c|c|}
\hline \multirow[b]{2}{*}{ Column } & \multicolumn{2}{|c|}{ Retention Time (min) } \\
\hline & Callitachykinin 1 & Callitachykinin II \\
\hline Delta Pak C18 & $58-61$ & $62-65$ \\
\hline Delta Pak C4 & $56-57$ & $58-59$ \\
\hline Vydac Phenyl & $50-51$ & $52-55$ \\
\hline Nova Pak C8 & $52-53$ & $54-59$ \\
\hline Vydac Diphenyl & $38-39$ & $40-45$ \\
\hline Spherex C18 & 53.2 & 56.7 \\
\hline I-125 Protein Pak & 39.6 & 43.4 \\
\hline Progel $^{\mathrm{TM}}$ TSK C 18 & 13.5 & 15.0 \\
\hline
\end{tabular}

The table shows the retention times of the myotropic peptide material as it eluted on the different columns on HPLC. On the first column, the myotropic material eluted in two zones with retention times of 58-61 min and $62-65 \mathrm{~min}$, respectively. The retention times of the myotropic material, during the different purification steps, can be followed by reading vertically. UV profiles from the three last column systems are illustrated in Fig. 1. 

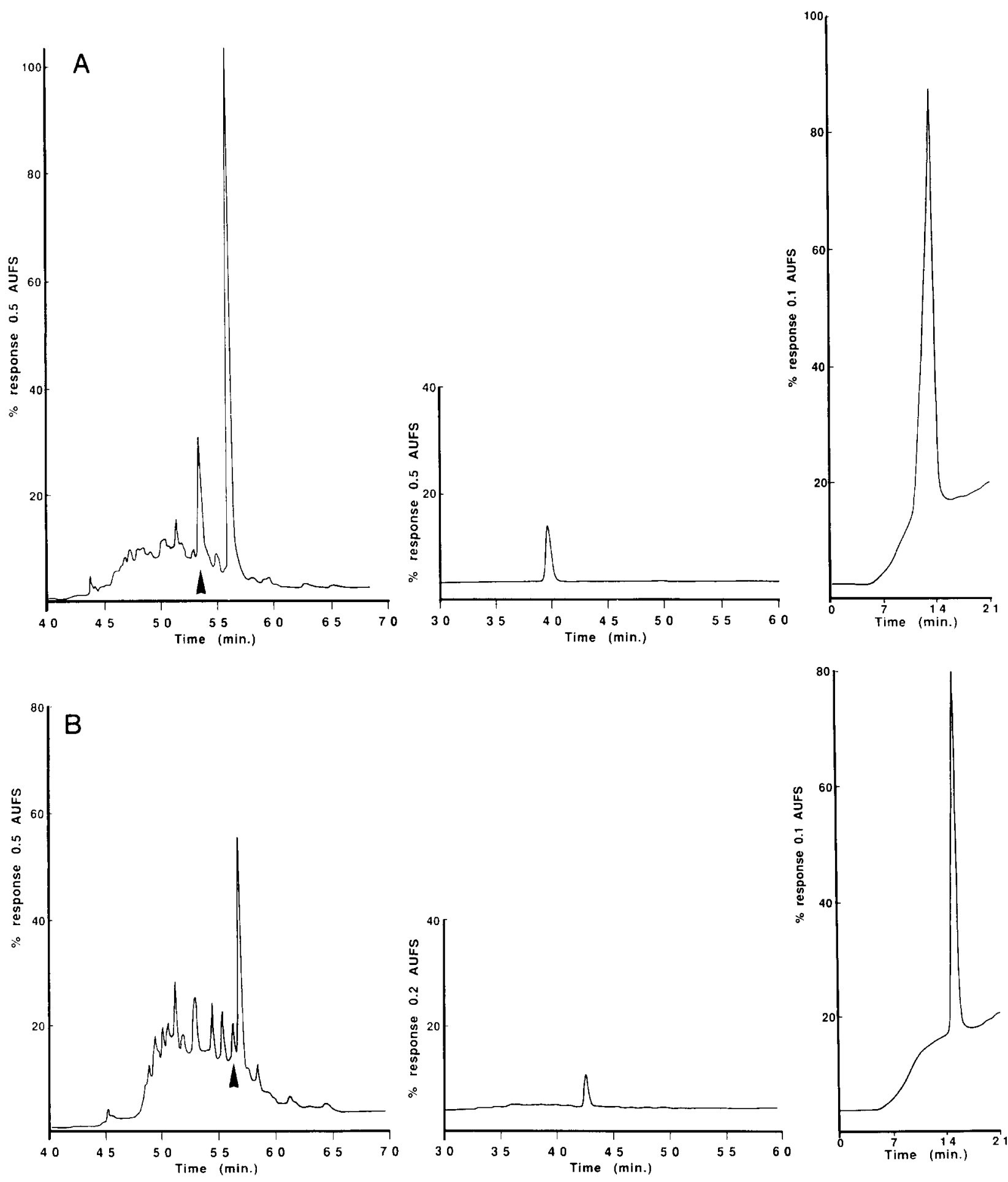

FIG. 1. Separation and purification of callitachykinin I (A) and II (B). The UV profiles represent the three last HPLC column systems: Spherex C18, I-125 Protein Pak, and Progel TSK C18 microbore. Peaks were collected manually and aliquots were tested in the hindgut contraction assay. The $x$-axes represent the retention times in minutes and the $y$-axes the percent $U V$ response at different absorption units full scale (AUFS), as measured at $214 \mathrm{~nm}$. Callitachykinin I eluted at $53.2 \mathrm{~min}$ (indicated by arrow) on the Spherex column and the material was pure on the two following columns (final column: $13.5 \mathrm{~min}$ ). Callitachykinin II eluted at $56.7 \mathrm{~min}$ on the Spherex column and the material was pure on the two following columns (final column: $15.0 \mathrm{~min}$ ). 
TABLE 2

AUTOMATED EDMAN SEQUENCING: AMINO ACID YIELDS OF NATURAL CALLITACHYKININ I AND II* AT EACH STEP

\begin{tabular}{ccc}
\hline Cycle Number & Amino Acid Residue Assignment & $\begin{array}{c}\text { Amount } \\
\text { (pmol) }\end{array}$ \\
\hline $\begin{array}{c}\text { Callitachykinin I } \\
1\end{array}$ & A (Ala) & 143 \\
2 & P (Pro) & 75 \\
3 & T (Thr) & 41 \\
4 & A (Ala) & 83 \\
5 & F (Phe) & 75 \\
6 & Y (Tyr) & 75 \\
7 & G (Gly) & 68 \\
8 & V (Val) & 79 \\
9 & R (Arg) & 38 \\
Callitachykinin II & & \\
1 & G (Gly) & 17.5 \\
2 & L (Leu) & 13.6 \\
3 & G (Gly) & 14.1 \\
4 & N (Asn) & 11.8 \\
5 & N (Asn) & 10.1 \\
6 & A (Ala) & 7.1 \\
7 & F (Phe) & 4.8 \\
8 & V (Val) & 1.7 \\
9 & G (Gly) & 5.9 \\
10 & V (Val) & 1.2 \\
11 & R (Arg) & 1.7 \\
\hline
\end{tabular}

* Twenty percent of the sample (approximately $20 \mathrm{pmol}$ ) was used for sequence analysis of callitachykinin II.

HPLC analysis of the PTH-amino acid generated in each cycle yielded the following primary sequences: 1 - (peptide eluting at $13.5 \mathrm{~min}$ on Progel TSK C18 column) Ala-Pro-Thr-Ala-PheTyr-Gly-Val-Arg, and 2-(peptide eluting at $15.0 \mathrm{~min}$ ) Gly-LeuGly-Asn-Asn-Ala-Phe-Val-Gly-Val-Arg. No other amino acids were detected during sequencing. The amino acid yields of the sequencing are listed in Table 2 . The peptides were assumed to be $C$-terminally amidated because locustatachykinins and urechistachykinins are $C$-terminally admidated. The amino acid sequences were confirmed by mass spectrometry (Table 3 ). The

TABLE 3

MASS SPECTROMETRY OF NATURAL AND SYNTHETIC CALLITACHYKININ I AND II

\begin{tabular}{|c|c|c|c|}
\hline \multirow[b]{2}{*}{ Peptide } & \multirow{2}{*}{$\begin{array}{l}\text { Calculated Mass } \\
\text { for }\left(\mathrm{MH}^{+}\right)^{*} \\
(\mathrm{~g} / \mathrm{mol})\end{array}$} & \multicolumn{2}{|c|}{$\begin{array}{c}\text { Observed Molecular Ion } \\
\left(\mathrm{MH}^{+}\right)^{\dagger}\end{array}$} \\
\hline & & Natural & Synthetic \\
\hline Callitachykinin I & 981.1 & 982.4 & 980.8 \\
\hline Callitachykinin II & 1103.3 & 1104.4 & 1103.2 \\
\hline
\end{tabular}

* The calculated molecular mass represents the theoretical value and includes an amidated $C$-terminus $\left(\mathrm{NH}_{2}\right)$. The molecular weights are based on monoisotopic amino acids.

$\dagger$ The natural-occurring peptides were analyzed by laser desorption mass spectrometry and the synthetic peptide masses were determined by fast atom bombardment mass spectrometry. Positively charged molecular ions were analyzed. The observed weights correspond to the molecular weight plus one mass unit for hydrogen.
TABLE 4

AMINO ACID COMPOSITION ANALYSIS OF SYNTHETIC CALLITACHYKININ I AND II

\begin{tabular}{ll}
\hline $\begin{array}{c}\text { Callitachykinin I } \\
\text { (APTAFYGVR) }\end{array}$ & \multicolumn{1}{c}{$\begin{array}{c}\text { Callitachykinin II } \\
\text { (GLGNNAFVGVR) }\end{array}$} \\
\hline Gly: $6.2 \mathrm{nmol}=1 \times \mathrm{G}$ & Asx: $5.7 \mathrm{nmol}=2 \times \mathrm{N}$ or D \\
Arg: $6.0 \mathrm{nmol}=1 \times \mathrm{R}$ & Gly: $9.7 \mathrm{nmol}=3 \times \mathrm{G}$ \\
Thr: $5.3 \mathrm{nmol}=1 \times \mathrm{T}$ & Arg: $2.9 \mathrm{nmol}=1 \times \mathrm{R}$ \\
Ala: $10.7 \mathrm{nmol}=2 \times \mathrm{A}$ & Ala: $3.0 \mathrm{nmol}=1 \times \mathrm{A}$ \\
Pro: $6.0 \mathrm{nmol}=1 \times \mathrm{P}$ & Val: $5.6 \mathrm{nmol}=2 \times \mathrm{V}$ \\
Tyr: $6.5 \mathrm{nmol}=1 \times \mathrm{Y}$ & Leu: $3.0 \mathrm{nmol}=1 \times \mathrm{L}$ \\
Val: $5.3 \mathrm{nmol}=1 \times \mathrm{V}$ & Phe: $2.9 \mathrm{nmol}=1 \times \mathrm{F}$ \\
Phe: $6.0 \mathrm{nmol}=1 \times \mathrm{F}$ & \\
\hline
\end{tabular}

two peptides are named callitachykinin I and II (referring to the genus name Calliphora) in accordance with other identified invertebrate tachykinin-like peptides.

Synthetic callitachykinin I and II were compared to the natural peptides. Co-chromatography of an equal mixture of natural and synthetic peptides on five different HPLC columns revealed that they both eluted in one single peak on each column system. This indicates that, for both callitachykinin I and II, the structures of the natural and amidated synthetic peptides are identical (including a $C$-terminal amidation of the natural peptides). The masses of the synthetic peptides, as revealed by mass spectrometry, are shown in Table 3. The calculated masses $\left(\mathrm{MH}^{+}\right)$of the peptides are based on the molecular weight of the monoisotopic forms of amino acids; callitachykinin I $\left(\mathrm{C}_{46} \mathrm{H}_{70} \mathrm{~N}_{13} \mathrm{O}_{11}\right) 981.1 \mathrm{~g} /$ mol, and callitachykinin II $\left(\mathrm{C}_{48} \mathrm{H}_{80} \mathrm{~N}_{17} \mathrm{O}_{13}\right) 1103.3 \mathrm{~g} / \mathrm{mol}$.

For both peptides the threshold concentration to cause an increase in the spontaneous contraction of the Leucophaea hindgut was determined (Table 5 and Fig. 2). Threshold concentrations for each natural peptide and their respective synthetic analogue were nearly identical. This also indicates that the natural peptides are $C$-terminally amidated, because the synthetic peptides were also. The amount of natural product obtained for each peptide was determined. For callitachykinin I a total of $3.499 \mathrm{nmol}$ was recovered after purification out of a total of 90,000 flies. For callitachykinin II a total of $1.837 \mathrm{nmol}$ was

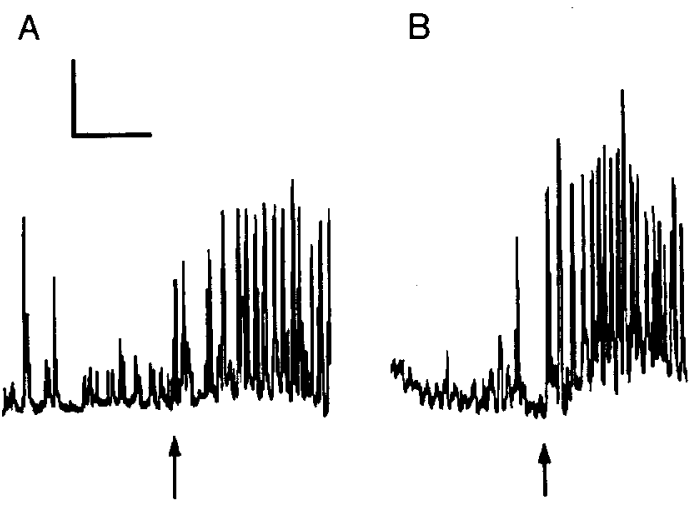

FIG. 2. Typical response of the isolated hindgut of the cockroach Leucophaea maderae to (A) $6.5 \times 10^{-10} \mathrm{M}$ of callitachykinin II natural product, and (B) $6.5 \times 10^{-10} \mathrm{M}$ of callitachykinin II synthetic product. The arrows indicate addition of peptide. Vertical calibration $=500 \mathrm{mmHg}$ displacement; horisontal time mark $=1 \mathrm{~min}$. 
TABLE 5

THRESHOLD CONCENTRATIONS OF NATURAL AND SYNTHETIC CALLITACHYKININ I AND II IN THE Leucophaea HINDGUT ASSAY

\begin{tabular}{cc}
\hline \multicolumn{1}{c}{ Peptide } & $\begin{array}{c}\text { Threshold Concentration } \\
(\overline{\mathrm{X}} \pm \mathrm{SD}, n=5)\end{array}$ \\
\hline Callitachykinin I & \\
$\quad$ Natural peptide & $1.19 \pm 0.41 \times 10^{-9} \mathrm{M}$ \\
$\quad$ Synthetic peptide & $1.27 \pm 1.04 \times 10^{-9} \mathrm{M}$ \\
Callitachykinin II & \\
$\quad$ Natural peptide & $3.60 \pm 2.68 \times 10^{-10} \mathrm{M}$ \\
Synthetic peptide & $3.72 \pm 2.73 \times 10^{-10} \mathrm{M}$ \\
\hline
\end{tabular}

recovered. Therefore, each fly contains $38.9 \mathrm{fmol}$ or $38.2 \mathrm{pg}$ of callitachykinin I and $20.4 \mathrm{fmol}$ or $22.5 \mathrm{pg}$ callitachykinin II.

Aliquots of natural callitachykinin I and II were tested in ELISA with an antiserum to locustatachykinin I (LomTK I). Both peptides reacted with a maximum response. In the kassinin ELISA, only callitachykinin II gave a positive immunoreaction under the described conditions. Aliquots from all remaining fractions from the first three HPLC column systems (excluding fractions containing the bioactive material) were also tested in the LomTK I and kassinin ELISAs. No immunoreaction was detected. The synthetic callitachykinin I and II react very similar to Lom TK $I$ in the ELISA with the LomTK I antiserum. In our test system, only callitachykinin II was recognized by the kassinin antiserum (Fig. 3).

\section{DISCUSSION}

In the present study we have described the purification and isolation of two novel myotropic peptides from the blowfly $\mathrm{Cal}$ liphora vomitoria. By a heterologous muscle contraction bioassay, using the hindgut of the cockroach Leucophaea maderae (16), myotropic peptide material was detected and followed through a series of different HPLC column systems until chromatographically pure peptides were obtained. The two peptides were named callitachykinin I and II. In addition to the bioassay, the isolated peptides were also analyzed in ELISA with antisera to the insect tachykinin-related peptide Lom TK I and the frog tachykinin kassinin. Both isolated peptides were immunopositive in the LomTK ELISA and one of them in the kassinin ELISA.
The two callitachykinins have the $C$-terminus in common: A-F-X-G-V-R-amide (where X represents $Y$ or V). The $N$-terminus, however, differs significantly (Table 6). The $C$-terminus portion, F-X-G-V-R-amide, is also identical to the locustatachykinins $(33,34)$, indicating their relationship. The degree of homology between callitachykinin I and locustatachykinin I is $67 \%$. The recently identified invertebrate peptides urechistachykinin I and II (19) also display some degree of sequence identity to the callitachykinins and the locustatachykinins by the $\mathrm{F}-\mathrm{X}_{1}$ $\mathrm{G}-\mathrm{X}_{2}$-R-amide in the $C$-terminus. As seen in Table 6, the similarities of the blowfly peptides to the vertebrate and cephalopod tachykinins and the mosquito sialokinins are less striking because the latter all have an F-X-G-L-M-amide $C$-terminal ( $\mathrm{X}$ is either a Y, V, I, or an F). However, an interesting observation is that callitachykinin I shares the sequence F-Y-G with uperolein, scyliorhinin, and the sialokinins, and callitachykinin II the sequence F-V-G with kassinin and neurokinin A (Table 6). Further support for the relation between the locustatachykinins, callitachykinins, and vertebrate tachykinins is that in several positions single nucleotide substitutions in the codons would yield peptides with additional homologous amino acids. Several neuropeptides seem to have the position 4 (counted from the $C$-terminus) variable and the other $C$-terminal amino acids constant. This composition is also seen in the insect myokinins, like leucokinins, which have a $C$-terminal core of F-X-S-W-G-amide $(16,17)$ and the allatostatins with the $C$-terminus Y-X-F-G-L-amide $(7,8)$.

It could not be conclusively determined, at this stage of the investigation, whether the isolated peptides are neuropeptides or not, because an extract of whole flies was used for the isolation. However, the fact that the isolated peptides were recognized by the locustatachykinin and kassinin antisera in ELISA tests gives some clues about the distribution, because the same antisera recognize interneurons in the CNS and endocrine cells in the midgut of the blowfly in immunocytochemical experiments $(24,25)$. Based on immunocytochemistry and immunochemistry, it was suggested that in the blowfly nervous system there are at least two tachykinin-related peptides, one resembling locustatachykinins and one sharing an epitope with kassinin $(24,25)$. This could be confirmed in the present study in ELISAs of the natural and synthetic callitachykinins I and II. Immunocytochemical studies indicated that the two Calliphora peptides may be colocalized in the blowfly central nervous system (25), but cross-reactivity could not be ruled out. When region-specific antisera to callitachykinin I and II have been produced, it will be possible to more accurately determine the peptide localization
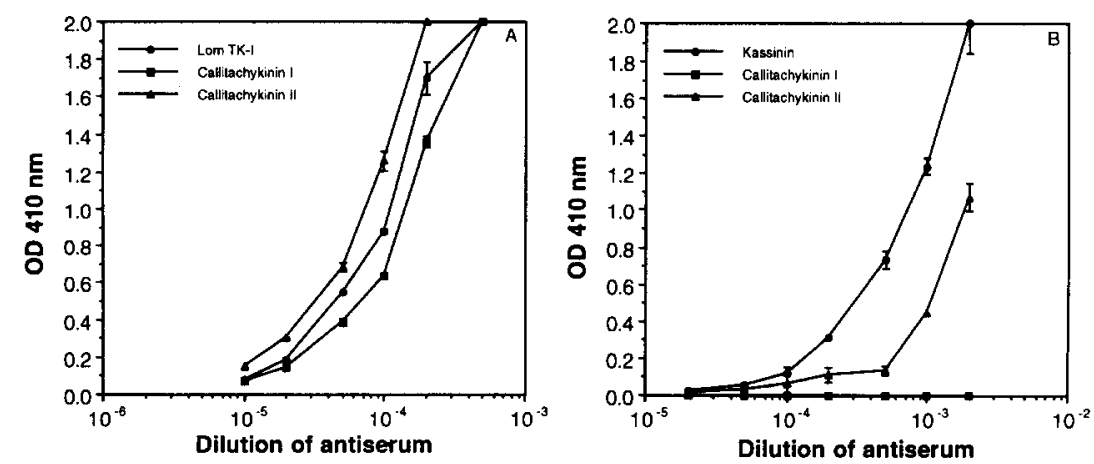

FIG. 3. ELISA tests on synthetic callitachykinin I and II. (A) Dilution series of LomTK I antiserum with 10 pmol peptide coated to the plate. (B) Dilution series of kassinin antiserum with 100 pmol peptide coated to the plate. Each test was performed in duplicate. The bars represent deviation from mean OD values. 
TABLE 6

AMINO ACID SEQUENCES OF CALLITACHYKININ I AND II IN COMPARISON TO VARIOUS TACHYKININS AND TACHYKININ-RELATED PEPTIDES

\begin{tabular}{|c|c|c|}
\hline Peptide Name* & Amino Acid Sequence $\dagger$ & Reference \\
\hline Callitachykinin I & $A-P-T-A-F-Y-G-V-R$ & This paper \\
\hline Callitachykinin II & G-L-G-N-N-A-F-V-G-V-R & This paper \\
\hline Locustatachykinin I & $G-P-S-G-F-Y-G-V-R$ & 33 \\
\hline Locustatachykinin II & $A-P-L-S-G-F-Y-G-V-R$ & 33 \\
\hline Locustatachykinin III & $A-P-Q-A-G-F-Y-G-V-R$ & 34 \\
\hline Locustatachykinin IV & $A-P-S-L-G-F-H-G-V-R$ & 34 \\
\hline Urechistachykinin I & L-A-QI-S-Q-F-V-G-S-R & 19 \\
\hline Urechistachykinin II & $A-A-G-M-G-F-F-G-A-R$ & 19 \\
\hline Sialokinin I & $\mathrm{N}-\mathrm{T}-\mathrm{G}-\mathrm{D}-\mathrm{K}-\mathbf{F}-\mathrm{Y}-\mathrm{G}-\mathrm{L}-\mathrm{M}$ & 2 \\
\hline Sialokinin II & $D-T-G-D-K-F-Y-G-L-M$ & 2 \\
\hline Substance P & $R-P-K-P-Q-Q-F-F-G-L-M$ & 4 \\
\hline \multicolumn{3}{|c|}{ Callitachykinin I in comparison to similar peptides } \\
\hline Callitachykinin I & $A-P-T-A-F-Y-G-V-R$ & This paper \\
\hline Locustatachykinin I & G-P-S-G-F-Y-G-V-R & 33 \\
\hline Sialokinin I & $N-T-G-D-K-F-Y-G-L-M$ & 2 \\
\hline Uperolein & PE-P-D-P-N-A-F-Y-G-L-M & 12 \\
\hline Scyliorhinin I & $A-K-F-D-K-F-Y-G-L-M$ & 5 \\
\hline Eledoisin & pE-P-S-K-D-A-F-I-G-L-M & 11 \\
\hline \multicolumn{3}{|c|}{ Callitachykinin II in comparison to similar peptides } \\
\hline Callitachykinin II & G-L-G-N-N-A-F-V-G-V-R & This paper \\
\hline Uperolein & PE-P-D-P-N-A-F-Y-G-L-M & 10 \\
\hline Kassinin & $D-V-P-K-S-D-Q-F-V-G-L-M$ & 1 \\
\hline Neurokinin A & $H-K-T-D-S-F-V-G-L-M$ & 21 \\
\hline Neurokinin B & D-M-H-D-F-V-G-L-M & 20 \\
\hline Locustatachykinin I & G-P-S-G-F-Y-G-V-R & 33 \\
\hline Urechistachykinin I & L-A-Q-S-Q-F-V-G-S-R & 19 \\
\hline
\end{tabular}

* Origin of peptides is as follows: eledoisin (cephalopod), kassinin and uperolein (amphibians), locustatachykinins and sialokinins (insects), neurokinins A and B, and substance P (mammals), scyliorhinin I (elasmobranch), urechistachykinins (echiuroid worm).

$\dagger$ All peptides are $C$-terminally amidated.

by immunocytochemistry and to corroborate possible colocalization.

The question whether the different peptides of the tachykinin family of each species have different functions and activate different receptor types or not is highly interesting. Studies of the mammalian nervous system have indicated the presence of sev- eral forms of tachykinin receptors and a multiplicity in tachykinin signaling (14,22). In another dipteran insect, Drosophila, two different putative tachykinin receptors have been demonstrated by recombinant DNA technique $(23,26)$, suggesting that insects also operate with complex tachykinin-like systems. The Drosophila tachykinin receptor (NKD) cloned by Monnier and coworkers (26) is a G-protein receptor complex displaying a $38 \%$ homology with a mammalian tachykinin receptor and responds specifically to locustatachykinin II when expressed.

Immunocytochemical studies of the blowfly and Drosophila have indicated that antisera to substance $P$ recognize a population of neurons in the brain and ventral ganglia that is distinctly different from that detected with antisera to locustatachykinin I and kassinin $(31,32)$. The recent discovery of the sialokinins I and II from salivary glands of the mosquito Aedes aegypti (2) confirms the existence of insect peptides with the $C$-terminus structure F-X-G-L-M-amide, characteristic of vertebrate tachykinins (Table 6). The neuronal localization of sialokinins has not yet been determined, but future work may answer the question whether the insect nervous system is utilizing two classes of tachykinin-like peptides: those related to locustatachykinins and callitachykinins, and others with a $C$-terminus, like the vertebrate tachykinins and the sialokinins.

In the blowfly, $C$. vomitoria, we now know the amino acid sequences of peptides representing three different families: FMRFamide-related peptides (8), allatostatins (9), and the tachykinins shown in the present investigation. At least 20 different peptide families have been indicated in various insects $(18,29,35)$, and it is likely that members of several additional families will be isolated from $C$. vomitoria in the future.

\section{ACKNOWLEDGEMENTS}

We thank the administrative management of the FAPRL, ARS USDA in whose laboratories the peptide isolations were performed. Financial support was from the Swedish Natural Science Research Council (NFR) to D.R.N. and from an NIH grant (NIH MH49538) to R.N. A travel grant to C.T.L. from NFR is also acknowledged. Anne Karlsson, Stockholm University is acknowledged for her help during the extractions and Maria Alicia Valadez and Tara Peterson, FAPRL, ARS, USDA, for the help running the bioassays during purification and threshold determinations. Dr. Ross Beier, FAPRL, ARS, USDA, is acknowledged for FAB-MS of the synthetic peptides. The natural peptides were sequenced at the University of Michigan Protein Structure Facility. Dr. Elvar Theodorsson-Norheim, Department of Clinical Chemistry, Karolinska Institute, is thanked for the generous gift of the kassinin antiserum and Bibbi Mayrhofer is acknowledged for help with the illustrations. We are grateful to Anders Abenius, EKOL AB, Linköping, Sweden, for providing us with about 80 liters of blowfly pupae.

\section{REFERENCES}

1. Anastasi, A.; Montecucci, P.; Erspamer, V.; Visser, J. Amino acid composition and sequence of kassinin, a tachykinin dodecapeptide from the African frog Kassina senegalensis. Experientia 33:857$858 ; 1977$.

2. Champagne, D. E.; Ribeiro, J. M. C. Sialokinin I and II: Vasodilatory tachykinins from the yellow fever mosquito Aedes aegypti. Proc. Natl. Acad. Sci. USA 91:138-142; 1994.

3. Chang, M. M.; Leeman, S. E.; Niall, H. D. Amino-acid sequence of substance $P$. Nature New Biol. 232:86-87; 1971.

4. Conlon, J. M.; Deacon, C. F.; O'Toole, L.; Thim, L. Scyliorhinin I and II: Two novel tachykinins from dogfish gut. FEBS Lett. 200: $111-116 ; 1986$.

5. Cook, B. J.; Holman, G. M. Comparative pharmacological properties of muscle functions in the foregut and the hindgut of the cockroach, Leucophaea maderae. Comp. Biochem. Physiol. [C] 61:291-29; 1978.

6. De Loof, A.; Schoofs, L. Homologies between the amino acid sequences of some vertebrate peptide hormones and peptides isolated from invertebrate sources. Comp. Biochem. Physiol. [B] 95:459468; 1990

7. Donly, B. C.; Ding, Q.; Tobe, S. S.; Bendena, W. G. Molecular cloning of the gene for the allatostatin family of neuropeptides from the cockroach Diploptera punctata. Proc. Natl. Acad. Sci. USA 90: $8807-8811 ; 1993$.

8. Duve, H.; Johnsen, A. H.; Sewell, J. C.; et al. Isolation, structure, and activity of -Phe-Met-Arg-Phe- $\mathrm{NH}_{2}$ neuropeptides (designated 
calliFMRFamides) from the blowfly Calliphora vomitoria. Proc. Natl. Acad. Sci. USA 89:2326-2330; 1992.

9. Duve, H.; Johnsen, A. H.; Scott, A. G.; et al. Callatostatins: Neuropeptides from the blowfly Calliphora vomitoria with sequence homology to cockroach allatostatins. Proc. Natl. Acad. Sci. USA 90: 2456-2460; 1993.

10. Erspamer, V. The tachykinin peptide family. Trends Neurosci. 4: $267-273 ; 1981$.

11. Erspamer, V.; Anastasi, A. Structure and pharmacological actions of eledoisin, the active endecapeptide of posterior salivary gland of Eledone. Experientia 18:58-61; 1962.

12. Erspamer, V.; Erspamer, G. F.; Linari, G. Occurrence of tachykinins (physalaemin- or substance P-like peptides) in the amphibian skin and their actions on smooth muscle preparations. In: Euler, U. S von; Pernow, B., eds. Substance P. Nobel symposium, 37. New York: Raven Press; 1977.

13. Fónagy, A.; Matsumoto, S.; Schoofs, L.; De Loof, A.; Mitsui, T. In vivo and in vitro pheromonotropic activity of two locustatachykinin peptides in Bombyx mori. Biosci. Biotech. Biochem. 56:1692-1693; 1992.

14. Hershey, A. D.; Polenzani, L.; Woodward, R. M.; Miledi, R.; Krause, J. E. Molecular and genetic characterization, functional expression, and $\mathrm{mRNA}$ expression patterns of a rabbit substance $\mathrm{P}$ receptor. Ann. NY Acad. Sci. 632:63-78; 1991.

15. Holman, G. M.; Cook, B. J. Pharmacological properties of excitatory neuromuscular transmission in the hindgut of the cockroach, Leucophaea maderae. J. Insect Physiol. 16:1891-1907; 1970.

16. Holman, G. M.; Nachman, R. J.; Wright, M. S. Comparative aspects of insect myotropic peptides. In: Epple, A.; Scanes, C. G.; Stetson, M. H., eds. Progress in comparative endocrinology. New York: Wiley-Liss; 35-39: 1990.

17. Holman, G. M.; Nachman, R. J.; Wright, M. S. Insect neuropeptides. Annu. Rev. Entomol. 35:201-217; 1990.

18. Holman, G. M.; Nachman, R. J.; Schoofs, L.; Hayes, T. K.; Wright, M. S.; De Loof, A. The Leucophaea maderae hindgut preparation: A rapid and sensitive bioassay tool for the isolation of insect myotropins of other insect species. Insect Biochem. 21:107-112; 1991.

19. Ikeda, T.; Minakata, H.; Nomoto, K.; Kubota, I.; Muneoka, Y. Two novel tachykinin-related neuropeptides in the echiuroid worm, Urechis unicinctus. Biochem. Biophys. Res. Commun. 192:1-6; 1993.

20. Kangawa, K.; Minamoto, N.; Fukuda, A.; Hisayuki, M. Neuromedin $\mathrm{K}$ : A novel mammalian tachykinin identified in the porcine spinal cord. Biochem. Biophys. Res. Commun. 111:533-540; 1984.

21. Kimura, S.; Okada, M.; Sugita, Y.; Kanazawa, I.; Munekata, E. Novel neuropeptides, neurokinin $\alpha$ and $\beta$ isolated from porcine spinal cord. Proc. Jpn. Acad. Sci. 59:101-104; 1983.

22. Krause, J. E.; Hershey, A. D.; Dykema, P. E.; Takeda, Y. Molecular biological studies on the diversity of chemical signalling in tachykinin peptidergic neurons. Ann. NY Acad. Sci. 579:254-272; 1990.
23. Li, X. J.; Wolfgang, W.; Wu, Y. N.; North, R. A.; Forte, M. Cloning, heterologous expression and developmental regulation of a Drosophila receptor for tachykinin-like peptides. EMBO J. 10:3221$3229 ; 1991$.

24. Lundquist, C. T.; Brodin, E.; Muren, J. E.; Nässel, D. R. Tachykininand leucokinin-related peptides in the nervous system of the blowfly: Immunocytochemical and chromatographical diversity. Peptides 14 : $651-663 ; 1993$

25. Lundquist, C. T.; Clottens, F. L.; Holman, G. M.; Riehm, J. P.; Bonkale, W.; Nässel, D. R. Locustatachykinin immunoreactivity in the blowfly central nervous system and intestine. J. Comp. Neurol. 341:225-240; 1994.

26. Monnier, D.; Colas, J. F.; Rosay, P.; Hen, R.; Borelli, E.; Maroteaux L. NKD, a developmentally regulated tachykinin receptor in Drosophila. J. Biol. Chem. 267:1298-1302; 1992.

27. Nachman, R. J.; Holman, G. M.; Haddon, W. F.; Hayes, T. K. Structure-activity relationships for myotropic activity of the gastrin/ cholecystokinin-like insect sulfakinins. Pept. Res. 2:171-177; 1989

28. Nachman, R. J.; Holman, G. M.; Hayes, T. K.; Beier, R. C. Structure-activity relationships for inhibitory insect myosupressins: Contrast with the stimulatory sulfakinins. Peptides 14:665-670; 1993.

29. Nässel, D. R. Neuropeptides in the insect brain-a review. Cell Tissue Res. 273:1-29; 1993

30. Nässel, D. R. Insect myotropic peptides: Differential distribution of locustatachykinin- and leucokinin-like immunoreactive neurons in the locust brain. Cell Tissue Res. 274:27-40; 1993.

31. Nässel, D. R.; Lundquist, C. T. Substance P-like immunoreactivity in a subpopulation of the FMRFamide-like immunoreactive neurons of Drosophila and Calliphora. Soc. Neurosci. Abstr. 15:364; 1989.

32. Nässel, D. R.; Lundquist, C. T.; Brodin, E. Diversity in tachykininlike peptides in the insect brain. In: Salánki, J.; Rózsa, K. S.; Elekes, K., eds. Neurobiology of invertebrates. Acta Biol. Hung. 43:175$188 ; 1992$.

33. Schoofs, L.; Holman, G. M.; Hayes, T. K.; Nachman, R. J.; De Loof, A. Locustatachykinins I and II, two novel insect neuropeptides with homology to peptides of the vertebrate tachykinin family. FEBS Lett. 261:397-401; 1990.

34. Schoofs, L.; Holman, G. M.; Hayes, T. K.; Kochansky, J. P.; Nachman, R. J.; De Loof, A. Locustatachykinin III and IV: Two additional insect neuropeptides with homology to peptides of the vertebrate tachykinin family. Regul. Pept. 31:199-212; 1990.

35. Schoofs, L.; Vanden Broeck, J.; De Loof, A. The myotropic peptides of Locusta migratoria: Structures, distribution, functions and receptors. Insect Biochem. Mol. Biol. 23:859-881; 1993.

36. Theodorsson-Norheim, E.; Brodin, E.; Norheim, E.; Rosell, S. Antisera raised against eledoisin and kassinin detect immunoreactive material in rat tissue extracts: Tissue distribution and chromatographic characterization. Regul. Pept. 9:229-244; 1984. 